\title{
Mercury Cycling in the Hells Canyon Complex of the Snake River, Idaho and Oregon
}

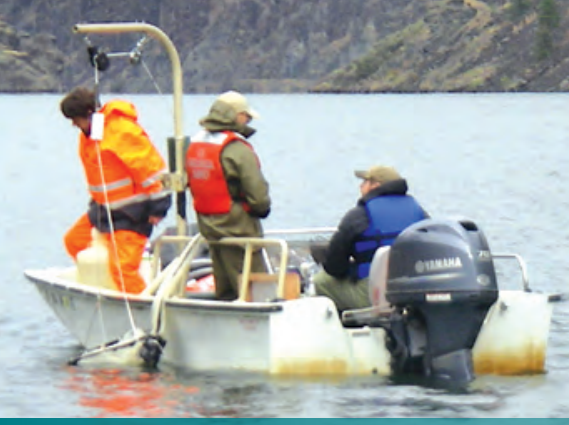

\section{Introduction}

The Hells Canyon Complex (HCC) is a hydroelectric project built and operated by the Idaho Power Company (IPC) that consists of three dams on the Snake River along the Oregon and Idaho border (fig. 1). The dams have resulted in the creation of Brownlee, Oxbow, and Hells Canyon Reservoirs, which have a combined storage capacity of more than 1.5 million acre-feet and span about 90 miles of the Snake River. The Snake River upstream of and through the HCC historically has been impaired by water-quality issues related to excessive contributions of nutrients, algae, sediment, and other pollutants. In addition, historical data collected since the 1960s from the Snake River and tributaries near the HCC have documented high concentrations of mercury in fish tissue and sediment (Harris and Beals, 2013). Data collected from more recent investigations within the HCC continue to indicate elevated concentrations of mercury and methylmercury in the water column, bottom sediments, and biota (Clark and Maret, 1998; Essig, 2010; Fosness and others, 2013). As a result, Brownlee and Hells Canyon Reservoirs are listed as impaired for mercury by the State of Idaho, and the Snake River from the Oregon and Idaho border through the HCC downstream to the Oregon and Washington border is listed as impaired for mercury by the State of Oregon.

Figure 1. Location of the Brownlee, Oxbow, and Hells Canyon Dams study area along the Snake River at the Idaho and Oregon border. These three dams and associated reservoirs comprise the Hells Canyon Complex (HCC).
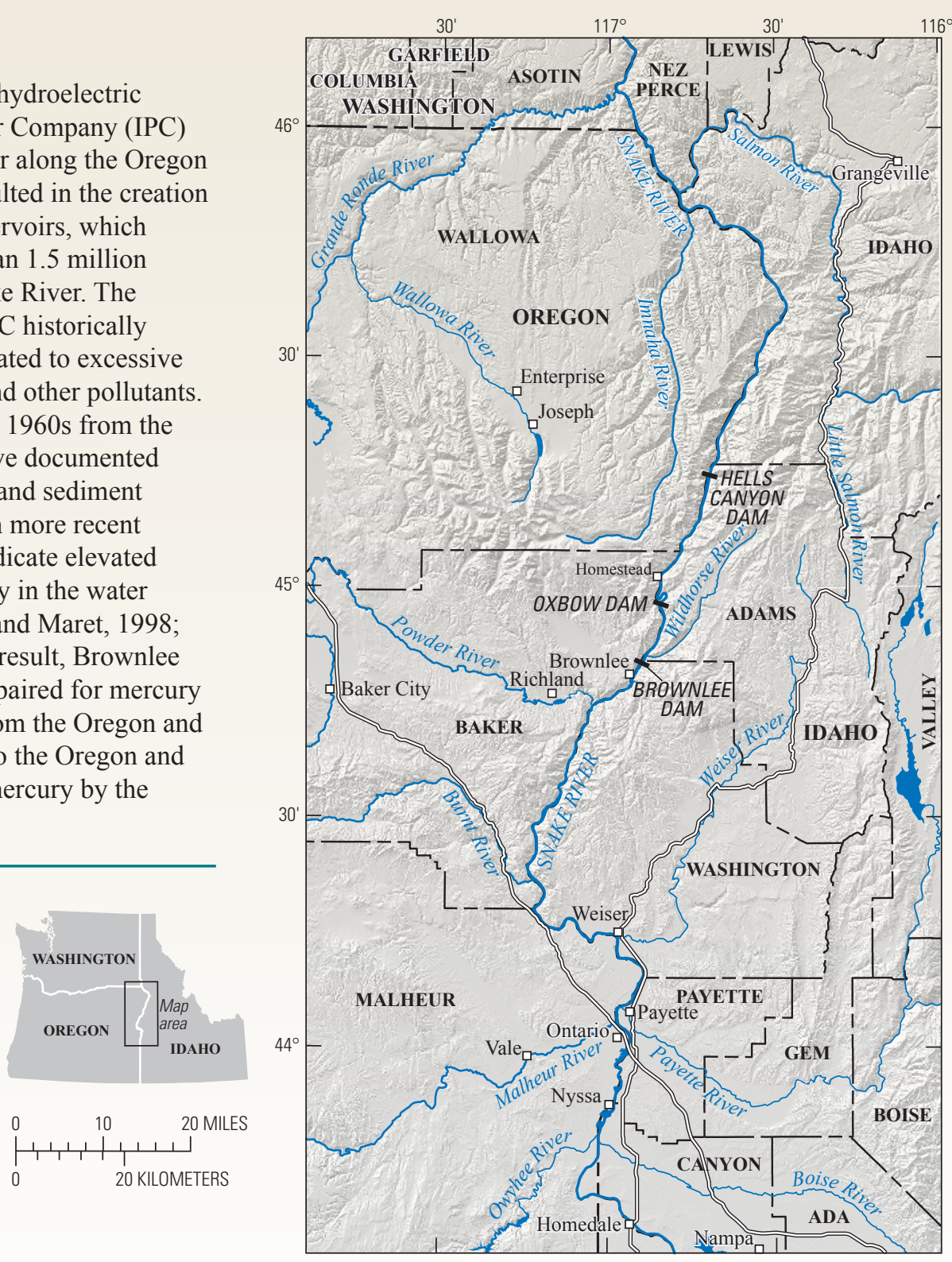


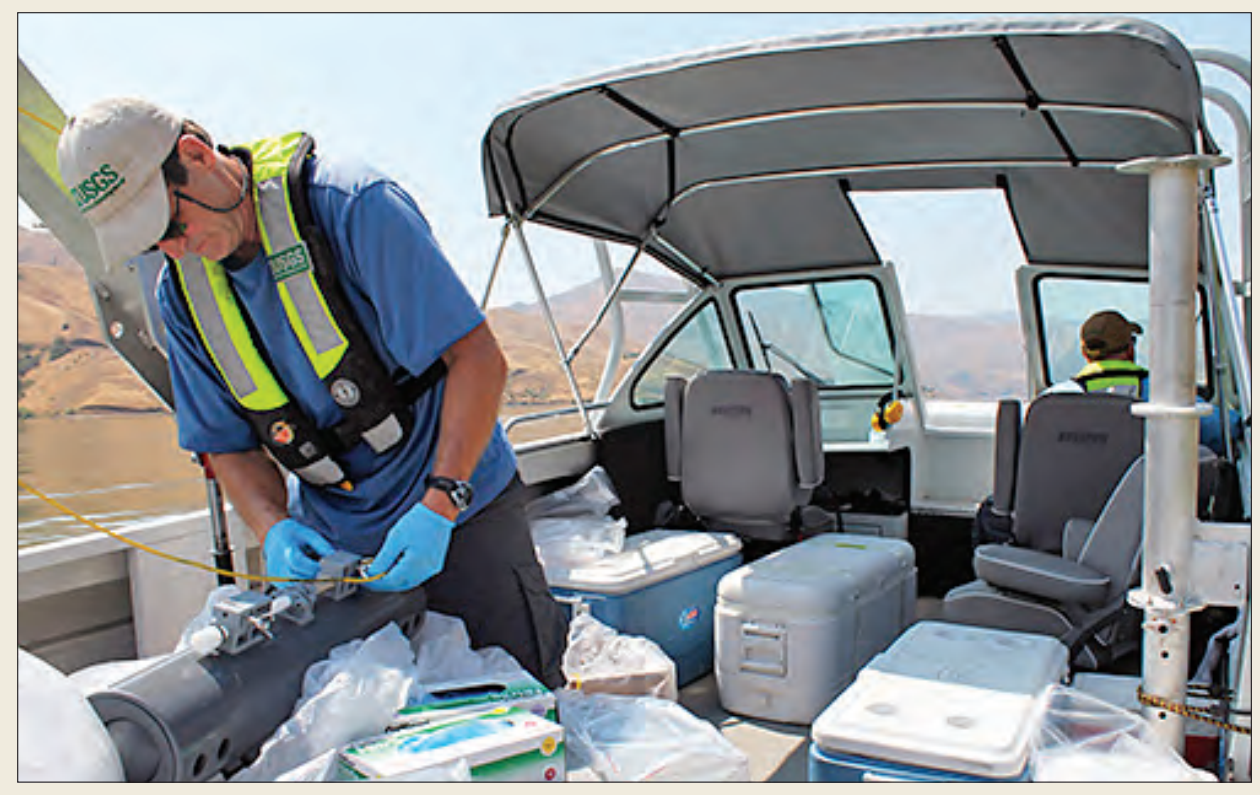

Water samples are collected from discrete depths at many locations in Hells Canyon Complex reservoirs to evaluate spatial and temporal variability in concentrations of mercury, methylmercury, and other constituents.

Recently, the need to evaluate a range of reservoir operational scenarios has prompted interest in developing a better understanding of mercury dynamics within the HCC. Altering how water is released from Brownlee Reservoir has the potential to change the thermal regime of the Snake River downstream of the HCC. The presence of species listed under the Endangered Species Act, such as bull trout (Salvelinus confluentus) and fall Chinook salmon (Oncorhynchus tshawytscha), has made evaluating downstream thermal conditions a priority. Because the mercury dynamics in the HCC are not well understood, however, it is not clear how altering releases from Brownlee Reservoir would affect mercury cycling within the HCC, and whether changes in operations would increase methylmercury exposure to downstream species. To address this and other issues related to mercury in the HCC, the U.S. Geological Survey (USGS), in collaboration with IPC and the Idaho Department of Environmental Quality (IDEQ), started an investigation in 2014 to evaluate key processes controlling mercury transport, cycling, and bioaccumulation in the Hells Canyon reach of the Snake River. Specific project objectives include:

- Determination of spatial variability and predominance of the specific forms of mercury in water, sediment, and biota;

- Examination of the factors controlling the spatial and temporal variability of mercury; and

- Determination of the mechanisms controlling mercury uptake, food-web transfer, and bioaccumulation.

This fact sheet describes current knowledge regarding mercury cycling in the $\mathrm{HCC}$, and the interdisciplinary project investigating the processes that lead to increased mercury bioaccumulation in the HCC ecosystem.

\section{Mercury Cycling in the Environment}

Mercury $(\mathrm{Hg})$ is a global pollutant that ultimately makes its way into every aquatic ecosystem through the hydrologic cycle. It has been well known as an environmental pollutant for several decades with the potential to have serious effects on human health (Wentz and others, 2014). Although mercury occurs naturally, industrialization has produced high levels of mercury in the environment and likely has resulted in high concentrations of mercury in fish on a global scale. Releases of mercury to the atmosphere from sources, such as burning of coal, artisanal mining, and incinerators, have resulted in long distance atmospheric transport and subsequent deposition and hydrologic transport through watersheds. Although atmospheric deposition of inorganic mercury probably contributes the majority of mercury to most aquatic systems, geologic and point-source discharges also may contribute mercury locally to streams, lakes, and other water bodies.

Atmospheric deposition provides mercury to the aquatic environment primarily as inorganic mercury $\mathrm{Hg}$ (II). Once in a water body, mercury can follow various pathways and ultimately is removed by burial, loss to the atmosphere, or outflow (fig. 2). Inorganic mercury also can undergo rapid transformations, driven by bacteria, where it is converted to methylmercury $\left(\mathrm{CH}_{3} \mathrm{Hg}^{+}\right.$or $\left.\mathrm{MeHg}\right)$. This step, referred to as inorganic mercury methylation, is ecologically important because:

- Methylmercury is much more toxic than inorganic mercury;

- Methylmercury easily moves into lower levels of the food web; and

- Methylmercury efficiently biomagnifies to a high level through food webs.

The exact mechanism(s) by which mercury is methylated, and subsequently enters the food chain, are still not completely understood, and probably vary among ecosystems. It is understood that the reaction can be carried out by microbes that thrive where oxygen levels are depleted, including sulfate $\left(\mathrm{SO}_{4}^{-2}\right)$ and iron-reducing bacteria. In the aquatic environment, this reaction often occurs at the sediment-water interface, in low-oxygen zones of the water column, and in areas where organic matter is decomposed. Demethylation, the process by which methylmercury is converted back to inorganic mercury or to elemental mercury $\left(\mathrm{HG}^{\circ}\right)$, occurs in the water column and in sediment. In the water column, demethylation is driven primarily by sunlight, and the resulting inorganic or elemental mercury can be volatilized from a water body back to the atmosphere. Various bacteria in sediment also can degrade methylmercury. 


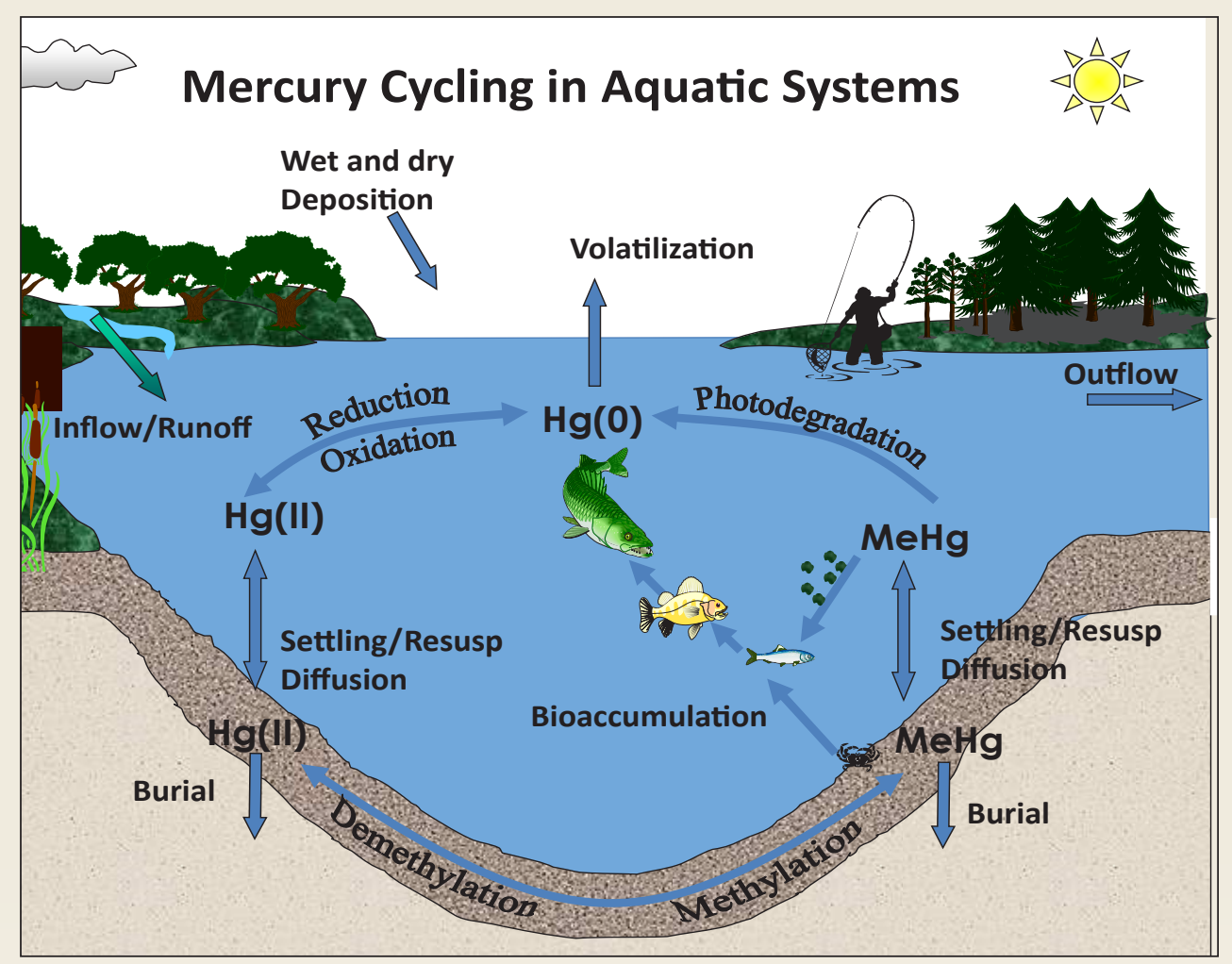

Figure 2. Mercury cycling pathways in aquatic environments are very complex. The various forms of mercury can be converted from one to the next; most important is the conversion of inorganic mercury to methylmercury (MeHg), the most toxic form. Ultimately, mercury ends up in the sediments, fish, and wildlife, or returns back to the atmosphere by volatilization.

How methylmercury enters the base of the food chain likely involves the direct adsorption of methylmercury from the water column by phytoplankton, and (or) consumption of methylmercury containing particles (including bacteria, decomposing organic matter, and living phytoplankton) by the next higher level in the food chain (likely zooplankton). Once in the food chain, methylmercury bioaccumulates in organisms (including humans) because it is taken up more rapidly than it can be eliminated. Methylmercury concentrations also increase two- to five-fold across trophic levels - a process called biomagnification. The combined effects of bioaccumulation and biomagnification are generally compounded the longer an organism lives. In aquatic systems, large, long-lived, predatory game fish and wildlife typically have the highest mercury levels. Although fish consumption has well-established health benefits, it is also the primary exposure pathway for methylmercury; health concerns arise when elevated concentrations of mercury are detected in fish targeted for commercial, subsistence, or recreational consumption.

\section{Mercury in the Hells Canyon Complex}

The water-quality conditions in the Snake River, together with the presence of the HCC dams, may be creating an environment that is efficient at converting inorganic mercury to methylmercury. Based on recent data collected from Hells Canyon Reservoirs (Fosness and others, 2013), methylmercury concentrations and the percentage of mercury in the form of methylmercury in the bottom sediments and deep parts of the water column are substantially elevated compared to other natural waters and reservoirs in Idaho, Oregon, and Washington. In addition to water and sediment, fish-tissue data indicate that methylmercury is elevated in the HCC food web. Samples of similar-sized smallmouth bass collected by the IPC during 2013 (fig. 3) indicate that starting in the Snake River near the inflow of Brownlee Reservoir (river mile [RM] 348), methylmercury concentrations in fish tissue generally increase downstream through the HCC, followed by a decrease downstream of Hells Canyon Dam toward the confluence of the Snake and Salmon Rivers (RM 188). Of 198 similar-sized smallmouth bass collected between the inflow to Brownlee Reservoir and the Salmon River confluence, 31 percent exceeded the State of Idaho human health fish-tissue criterion for mercury of 0.3 milligram per kilogram $(\mathrm{mg} / \mathrm{kg}$; wet weight), and 96 percent exceeded the more stringent State of Oregon criterion of $0.04 \mathrm{mg} / \mathrm{kg}$ (wet weight).

Although much of the mercury in the environment originates from anthropogenic sources, the accumulation in freshwater aquatic ecosystems is not a simple function of local or regional mercury inputs. Studies show that even sites with similar mercury inputs can produce fish with methylmercury concentrations ranging more than an order of magnitude (Scudder and others, 2009; Wentz and others, 2013). However, based on previous mercury research, there are characteristics within the HCC that are consistent with increased susceptibility to methylmercury accumulation. The Snake River changes from a riverine to a lacustrine, or laketype environment in the upstream reach of the HCC. As it transitions to a lacustrine system, it delivers abundant nutrients, organic material, and sediments, much of which settles to the bottom in the upstream transition zone. As with many large water bodies, the reservoirs in the HCC undergo summertime thermal stratification. As air temperatures rise each spring, heat from the sun warms the inflowing river water and the surface layer in the reservoirs. The warm water, direct sunlight, and abundant nutrients, in the upstream riverine environment and the reservoirs, provide an ideal environment for phytoplankton production. 

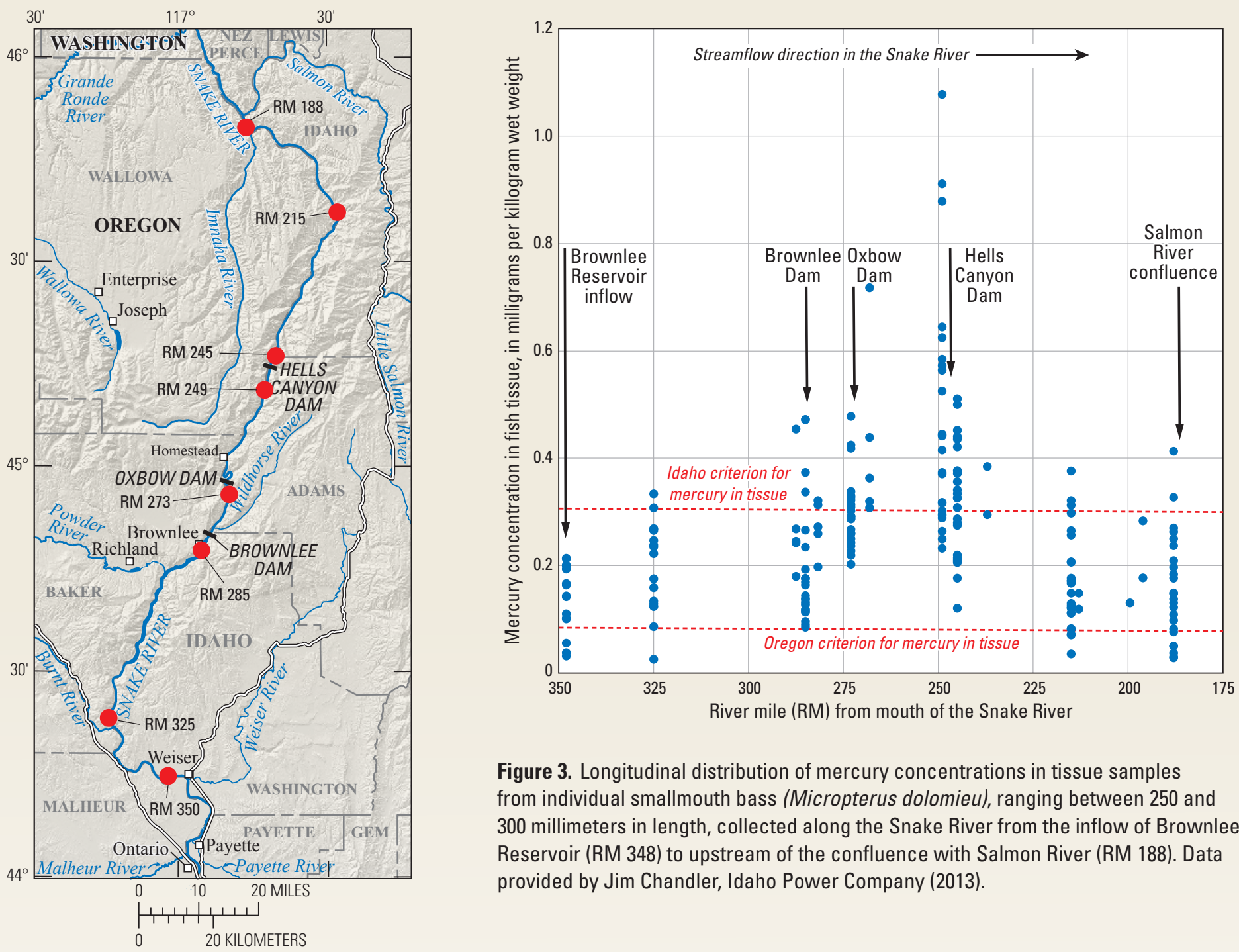

Figure 3. Longitudinal distribution of mercury concentrations in tissue samples from individual smallmouth bass (Micropterus dolomieu), ranging between 250 and 300 millimeters in length, collected along the Snake River from the inflow of Brownlee Reservoir (RM 348) to upstream of the confluence with Salmon River (RM 188). Data provided by Jim Chandler, Idaho Power Company (2013).

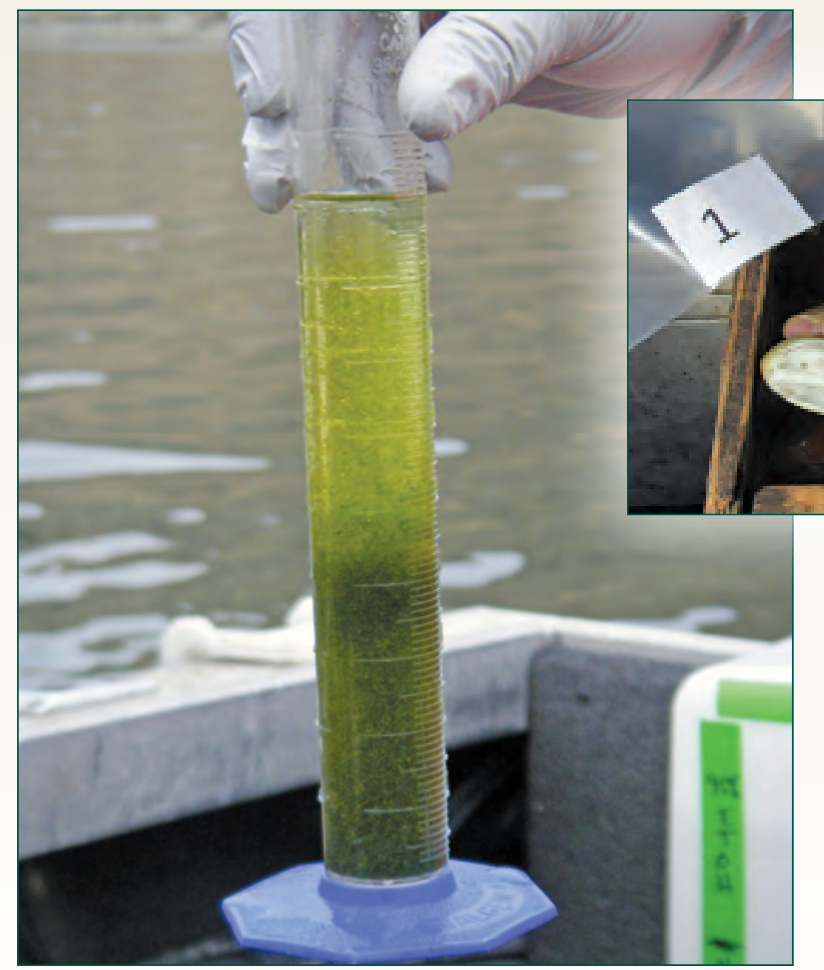

Zooplankton (far left) and fishtissue (left) samples are collected to evaluate mercury uptake and food web transfer in the Hells Canyon Complex.

Because warm water near the surface is less dense than the colder underlying water, thermal stratification results in a warmer layer of water (epilimnion) that floats over a colder, denser underlying layer of water (hypolimnion). As algae and organic material delivered by the inflowing water and produced in the epilimnion sink through the water column, they are decomposed by aerobic bacteria, which accelerate the depletion of dissolved oxygen in the water column (fig. 4). 


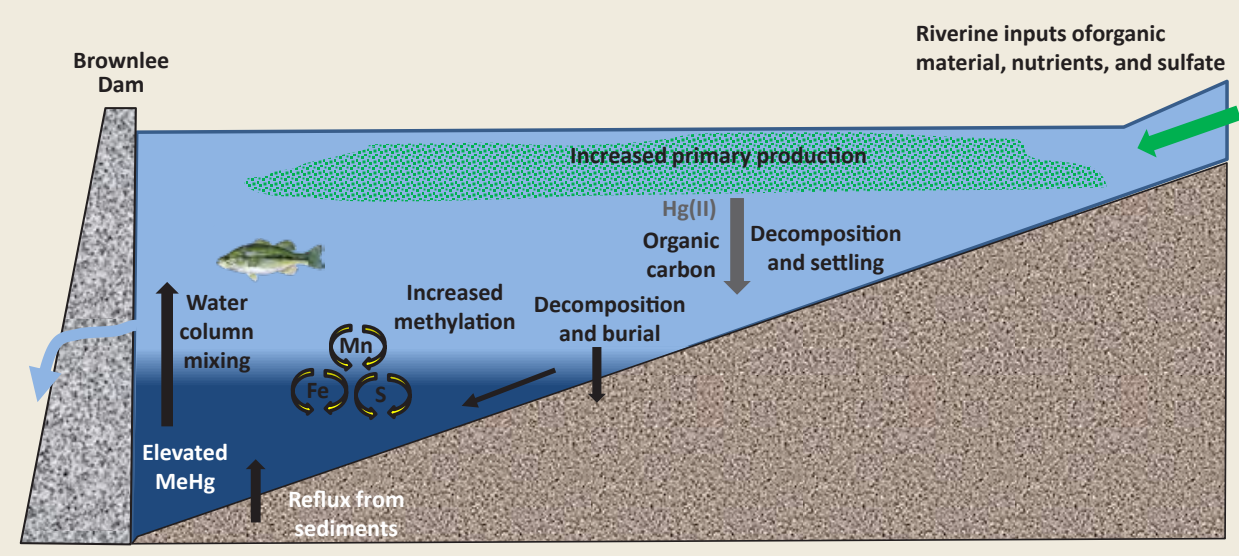

Figure 4. Conceptual model of organic enrichment, decomposition, and mercury cycling in Brownlee Reservoir.

As oxygen is consumed, conditions in the hypolimnion and in the deeper layers of the upstream riverine and transition zones can become anoxic (without oxygen) and anaerobic bacteria, which include those that convert inorganic mercury to methylmercury, begin to decompose organic material. Seasonal water column sampling in the HCC indicates that methylmercury concentrations increase in the hypolimnion during the summer and autumn each year as Brownlee and Hells Canyon Reservoirs thermally stratify and oxygen is consumed at depth. In Brownlee Reservoir, oxygen consumption and anoxic conditions in the hypolimnion begin to occur in the spring near river mile 310 where the river transitions to a lacustrine environment (fig. $5 A$ ). By late summer Brownlee Reservoir is typically anoxic throughout the hypolimnion (fig. 5B). During late autumn and early winter, thermal stratification of the water column in the reservoirs breaks down, causing methylmercury in the hypolimnion to mix with water from the rest of the water column where the methylmercury can be exported downstream. The annual cycle begins again in the spring as Brownlee and Hells Canyon Reservoirs begin to restratify.

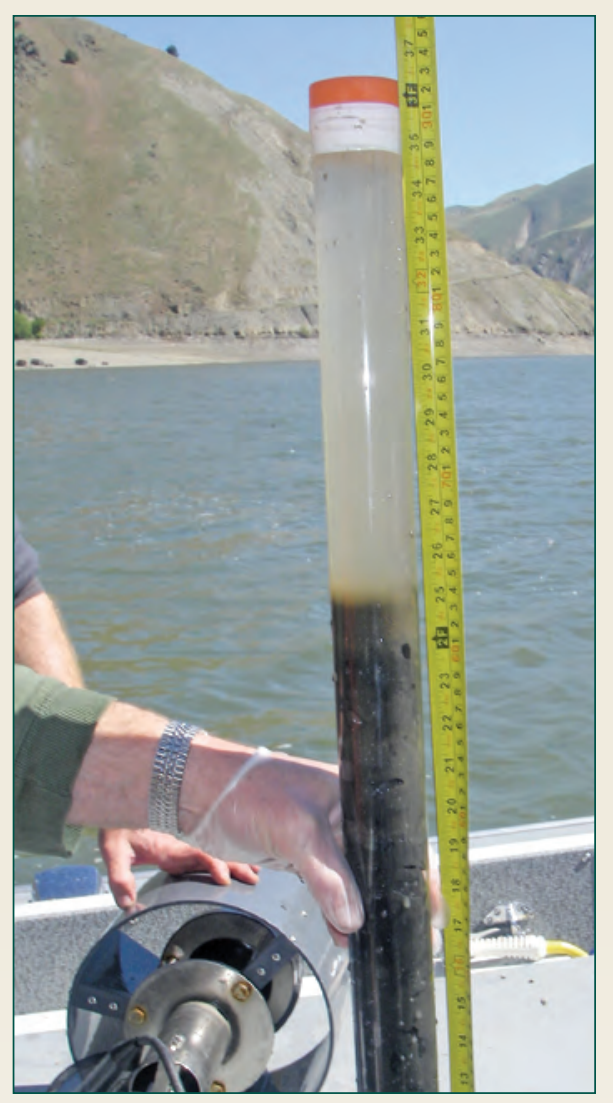

Surficial and core sediment samples are collected from the bottom of Hells Canyon Complex reservoirs to evaluate potential contributions of methylmercury and other constituents from sediment to the hypolimnion.
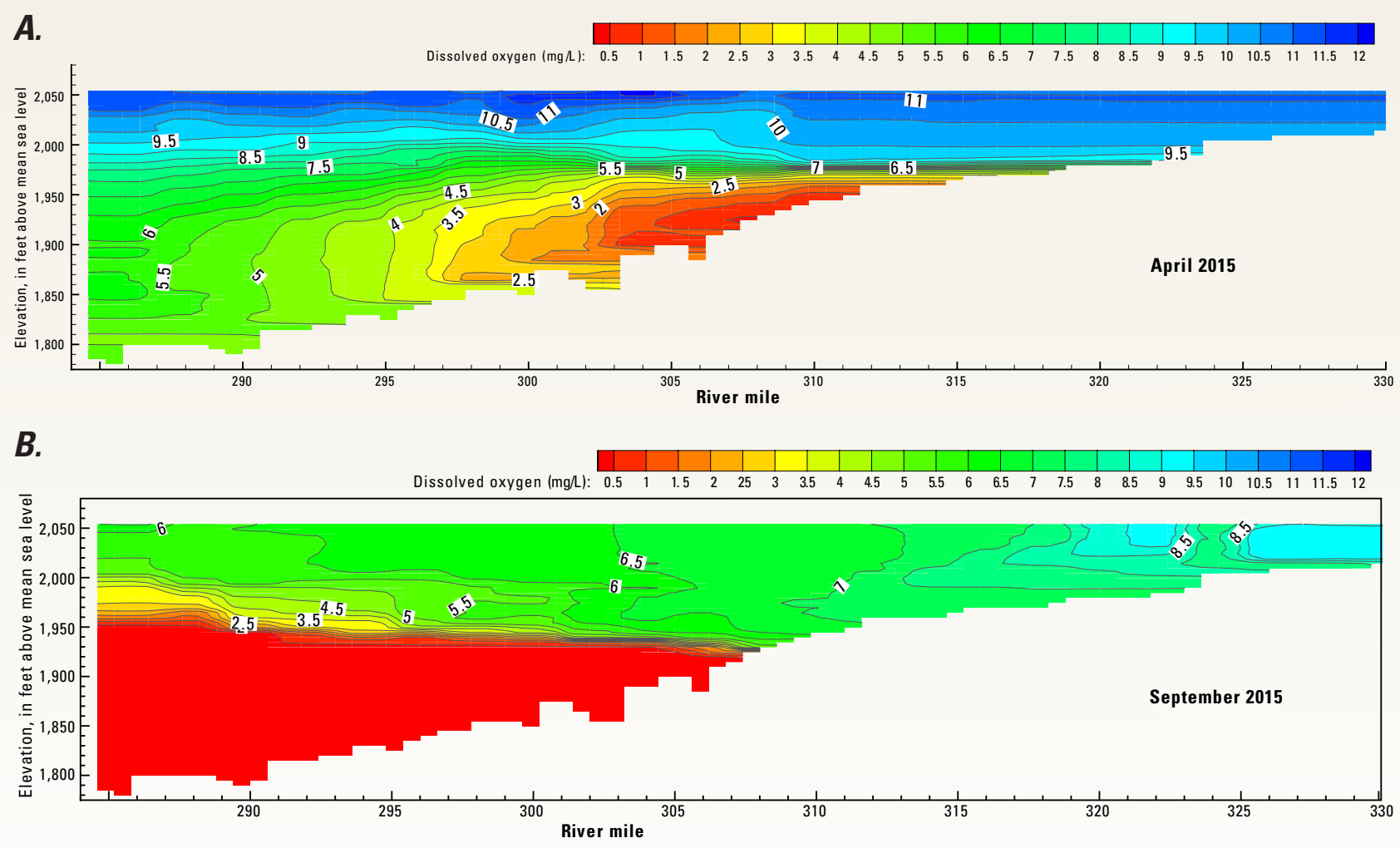

Figure 5. Oxygen consumption and anoxic conditions in Brownlee Reservoir typically start in the spring near river mile 310 where the Snake River delivers abundant nutrients and organic matter to the reservoir $(A)$. By late summer, the reservoir is typically completely stratified and devoid of oxygen throughout the hypolimnion $(B)$. 
Much of the foundational work on mercury in freshwater aquatic environments has focused on natural lakes, and accordingly, mercury contamination in streams and reservoirs is an important area of research. The Snake River in the HCC provides an ideal opportunity to evaluate potential important drivers of mercury accumulation in rivers and established reservoir ecosystems,

for instance:

- How does the water quality of the inflowing Snake River affect the mercury dynamics in the HCC?

- How does the seasonal cycle of reservoir stratification and destratification influence the mass transport of mercury into and out of the HCC?

- Are reservoir bottom sediments a source of stored inorganic mercury that can be methylated and transported to the water column?

- Where in the water column, and during what time of the year, is methylmercury entering the food web?

- Do differences in food web complexity result in greater mercury bioaccumulation in the reservoirs of the HCC compared to upstream and downstream of the HCC?

The USGS, in collaboration with IPC and IDEQ, initiated its investigation of mercury in the HCC in the spring of 2014. The study plan uses both routine and intensive assessments to evaluate temporal and spatial patterns in the production, transport, and bioaccumulation of mercury and methylmercury throughout the HCC. The routine assessments include:

- Regular water-column profiles of physical characteristics related to stratification;

- Chemical sampling from discrete parts of the water column in Brownlee and Hells Canyon Reservoirs;

- Reservoir inflow and outflow sampling to evaluate the mercury mass balance; and

- Zooplankton and fish sampling to evaluate temporal patterns in mercury uptake and food web transfer.

Results from the routine assessments will provide a basic understanding of the spatial and temporal occurrence of the forms of mercury, and will explain how those forms are transported into and through the HCC. Biannual intensive assessments are designed to provide more complete spatial coverage and in-depth understanding of factors related to methylation rates in sediment and the water column; photodegradation of methylmercury and volatilization from the water column; the role of organic matter and water chemistry in mercury methylation; and biomagnification through different compartments of the food web. Although the study will likely take between 5 and 8 years to complete, the exact timeline may vary because the study will use an adaptive science strategy providing opportunities to modify the approach based on the results. The results from this study will provide resource managers an improved scientific understanding of the hydrologic, geochemical, and ecological processes controlling mercury cycling in the HCC. In addition, a long-term goal is to develop a predictive model for methylmercury, which can be used to evaluate the effects of potential future operational and water-quality changes in the Snake River that could affect the aquatic resources within the HCC and downstream. The study results also should be transferrable to other large existing reservoirs and aquatic ecosystems where mercury problems may exist, or may occur in the future.

\section{References Cited}

Clark, G.M., and Maret, T.R., 1998, Organochlorine compounds and trace elements in fish tissue and bed sediments in the Lower Snake River Basin, Idaho and Oregon: U.S. Geological Survey Water-Resources Investigations Report 98-4103, 35 p.

Essig, D.A., 2010, Arsenic, mercury, and selenium in fish tissue and water from Idaho's major rivers-A statewide assessment: Boise, Idaho Department of Environmental Quality, 64 p.

Fosness, R.L, Naymik, Jesse, Hopkins, C.B., and DeWild, J.F., 2013, Water column and bed-sediment core samples collected from Brownlee Reservoir near Oxbow, Oregon, 2012: U.S. Geological Survey Data Series 809, 44 p.

Harris, R.C., and Beals, C., 2013, Hells Canyon Complex mercury data assessment: Draft Technical Memorandum prepared for Idaho Power Company by Reed Harris Environmental Ltd., 38 p.

Scudder, B.C., Chasar, L.C., Wentz, D.A., Bauch, N.J., Brigham, M.E., Moran, P.W., and Krabbenhoft, D.P., 2009, Mercury in fish, bed sediment, and water from streams across the United States, 1998-2005: U.S. Geological Survey Scientific Investigations Report 2009-5109, 74 p.

Wentz, D.A., Brigham, M.E., Chasar, L.C., Lutz, M.A., and Krabbenhoft, D.P., 2014, Mercury in the nation's streamsLevels, trends, and implications: U.S. Geological Survey Circular 1395, $90 \mathrm{p}$.

Authors:

Gregory M. Clark', Jesse Naymik², David P. Krabbenhoft'

Collin A. Eagles-Smith', George R. Aiken', Mark C. Marvin-

DiPasquale ${ }^{1}$, Reed C. Harris ${ }^{3}$, and Ralph Myers ${ }^{2}$

'U.S. Geological Survey.

"daho Power Company.

${ }^{3}$ Reed Harris Environmental Ltd.

All photographs provided by U.S. Geological Survey.

For more information:

Director, Idaho Water Science Center,

U.S. Geological Survey

230 Collins Road, Boise, Idaho 83702

http://id.water.usgs.gov/

Publishing support provided by the U.S. Geological Survey, Science Publishing Network, Tacoma Publishing Service Center 